\author{
Anetta Breczko \\ University of Białystok \\ breczko@uwb.edu.pl \\ ORCID ID: https://orcid.org/0000-0003-4856-5396 \\ Marta Andruszkiewicz \\ University of Białystok \\ andruszkiewicz@uwb.edu.pl \\ ORCID ID: https://orcid.org/0000-0003-3731-7258
}

\title{
The Question of the Value of Human Life in Theoretical Discussions and in Practice. A Legal Philosophical and Theory of Law Perspective
}

\begin{abstract}
The value of human life has a basis in cultural norms, both moral and religious. In democratic states it is reflected in the right to life, which has become a foundation for all other human rights and freedoms. Nonetheless, in contemporary legal philosophical thought, the treatment of life as an absolute value and as absolutely inviolable is not the only perspective. Alongside the traditional principle of the sanctity of life, there are those who propose to give precedence to its quality. That quality is gradable and depends on biological and genetic factors. Such a view brings to light new aspects of legal interference in the domain of the life of individuals. It justifies, for example, the permissibility of abortion in the case of a foetus suffering lethal defects. It raises the possibility of allowing claims for redress for harm done by bringing about wrongful life ("life that is not worth living") or wrongful birth. These issues are highly controversial from an axiological standpoint, while also becoming a source of moral dilemmas. At the same time, given the progress currently being made in biotechnology, they demand legal regulation.
\end{abstract}

Key words: quality of life, sanctity of life, wrongful life, wrongful birth, prenatal injuries

\section{Introduction}

The concept of quality was originally applied to the domain of consumption and material objects. In recent decades it has come to be transferred from the level of "thing" to the level of "person". In the wealthy democracies, material comfort has become something universal. "Quality", which was previously a function in 
the struggle for universal welfare and stabilisation, has become a criterion for the classification of life (quality of life). Beginning from the 1960s, as a result of globalisation, the pluralisation of moral attitudes and world views, and rapid progress in science (especially biomedicine and biotechnology), intervention in the domain of human life started to become ever more bold, aiming to promote those forms of life that would fulfil "high quality standards". At the same time a "new quality" appeared in ethical discussions, previously dominated by the traditional sanctity of life ethics ${ }^{1}$. This has led to controversies and debates concerning the limits of medical interference in human life, and its legal regulation.

The confrontation between the principles of sanctity of life and quality of life characterises contemporary bioethical discourse. It should be noted that the primary subject of bioethical debates is life as such (bios). Bioethics is currently becoming primarily a form of moral management of human life. It seeks solutions that will respect the dignity of a person, favour the integral development of human beings in accordance with their nature, and also ensure stable development for both present and future generations. The chief goal of bioethics, then, may be described most generally as improved quality of life ${ }^{2}$.

Doctors, bioethicists and lawyers are today faced with the question of whether every human life (as an overriding, inviolable and ultimate value) is deserving of legal protection, or whether such protection should apply to life of adequate quality ${ }^{3}$. It is becoming necessary to choose the values and principles on which civilisation in the 21 st century is to be founded. Making such a choice may prove to be extremely difficult, assuming that it is even possible. Let us note that sanctity of life ethics and quality of life ethics are two entirely divergent visions of reality, born out of quite different philosophical traditions. Nonetheless, the working out of a common "moral grammar" would appear to be essential for a globalised world, particularly in view of the practical possibilities being offered by medicine.

1 See more: L. Nordenfelt, Quality of Life. Health and Happiness, Avebury, Aldershot 1993, M. Nussbaum, A. Sed (eds.), The Quality of Life, Clarendon Press, Oxford 1993, W. Chańska, Nieszczęsny dar życia. Filozofia i etyka jakości życia w medycynie współczesnej, Wrocław 2009, D. Ślęczek-Czakon, Problem wartości i jakości życia w sporach bioetycznych, Katowice 2004, D. Szawarski, Wartość życia, Etyka 1984, no 21, pp. 41-69.

2 M. Bazela, Życie wysokiej jakości, czyli po co nam bioetyka?, Archeus. Studia z bioetyki i antropologii filozoficznej 2004, no. 5, pp. 5-13.

3 J. Umiastowski, Wokół kodeksu etyki lekarskiej, Ethos 1994, nos. 1-2, p. 244. 
The Question of the Value of Human Life in Theoretical Discussions and in Practice...

\section{Sanctity of life ethics versus quality of life ethics}

Sanctity of life ethics is rooted in Christian anthropology and personalism ${ }^{4}$. It has been the foundation of traditional Western ethics. It is based on the principle of the sanctity of human life, and it assumes a natural moral order and the integral nature of a human being as a unity of body and soul. It considers human life to have inalienable value, regardless of its character and quality. Life is held to be inviolable from the moment of conception up to the moment of death. The basic goal of this ethic is the protection of the human person; such as it is, and not such as it might become through technical intervention. The concept of sanctity is not to be understood here in a strictly theological sense. It denotes a certain perfection, fullness, inviolability. And it is this sense that attaches to the phenomenon of human life, which is a value in itself, and at the same time a fundamental value. The realisation of other values proves to be possible only where there is life. In medicine, the principle of the sanctity of life is associated with a prohibition on subjecting decisions about a patient's life to an assessment of the quality of that life.

Quality of life ethics, on the other hand, has its roots in the Enlightenment tradition, which was based on rationalism, scientism, agnosticism, mechanistic materialism and utilitarianism. Quality of life ethics takes account of the aforementioned assumptions. It attempts to respect the pluralism of world views and the autonomy of individuals. At its foundation lies the principle of quality of life, which is gradable and may be dependent on various properties which condition its desired status. The way of understanding this "quality" is not set in stone, but is subject to evolution depending on cultural, economic and political factors, as well as scientific findings. Modification and revision of the principle is possible through democratic social dialogue. It is society that is to decide, through consensus, whether particular behaviours are to be accepted or rejected. The goal of quality of life ethics is to obtain results that might satisfy the greatest number of people, while minimising social harm. The making of choices may be assisted by the principles of utility and benevolence.

The term "quality of life" is multidimensional and polysemous. Its meaning may be considered from a strictly medical point of view, but also from a broader perspective, encompassing for example the social (linked with economic) and ethical (axiological) planes.

In medicine the term is used in the context of health care and health protection. We may note that a description of the emotional, physical and social welfare of a human individual confirms his or her capacity to function normally (that is, to perform life tasks). Health-related quality of life may thus be significantly impaired by

See John Paul II, Encyclical: Evangelium Vitae. On the value and inviolability of human life, Vatican 1995, no. 2 . 
illness. The medical sense of quality of life also takes on a social meaning. Economic decisions concerning principles of access to preventive and therapeutic medicine may lead to improved quality of life and increased longevity - or the reverse.

In its ethical meaning, the term refers to the moral principles that are used to evaluate the quality of life. Such an evaluation becomes a basis for the taking of decisions on the continuation or curtailment of life. The axiological dimension of quality of life is usually considered in opposition to sanctity of life ethics. Roman Tokarczyk writes that an insurmountable antinomy is drawn between sanctity of life ethics and quality of life ethics. The first is characteristic of religious systems (particularly Catholicism). It demands moral and legal protection for the whole of a human life (from conception to natural death) and is characterised by rigorism. The second - the secular quality of life ethics - is less rigoristic. While upholding the principle of protection of human life, it admits many exceptions $s^{5}$. For example, it provides for the possibility of aborting a foetus with untreatable lethal defects that will lead to miscarriage or the inevitable death of the child soon after birth ${ }^{6}$.

\section{The value of life according to quality of life ethics and its opponents}

Adherents of quality of life ethics share the conviction that the value of life may be different depending on its quality. This conviction is founded on an inclination to make an ontological separation between biological life and personal life. They believe that, for a life to be the life of a person, it must fulfil certain conditions, such as selfawareness, understanding of future and past, emotional balance, capacity for selfcontrol, ability to care for others, and curiosity. ${ }^{7}$ They also refer to the potential ability to establish interpersonal relations ${ }^{8}$, and the requirement of a minimal independence from the surroundings 9 . They accept that a poorly functioning human body may be equal in value to a well-functioning animal body ${ }^{10}$.

From the standpoint of the quality of life principle, attempts are made to evaluate whose life is worth living, and whose is not (in the latter case the term wrongful life is applied). By this principle, effort is made to determine a lower bound for the minimum level below which human life ought not to be sustained and rescued ${ }^{11}$.

5 R. Tokarczyk, Jakość życia jako prewartość, http://romantokarczyk.pl/juris/bio8.html (access 6.4.2018); D. Ślęczek-Czakon, Problem wartości..., op. cit., p. 238.

6 Furthersee: W. Chańska, Nieszczęsny dar..., op. cit.

7 J. Fletcher, Indicators of Humanhood: A Tentative Profile of Man, The Hastings Center Report 1972, vol. 2, p. 14.

8 R.A. McCormick, The Quality of Life, the Sanctity of Life, The Hastings Center Report 1978, vol. 8, pp. 30-36.

9 Further see: E.E. Shelp, Born to die? Deciding the fate of critically ill newborns, New York 1986.

10 Further see: P. Singer, O życiu i śmierci. Upadek etyki tradycyjnej, Warsaw 1994.

11 P. Singer, $O \dot{z} y c i u . . .$, op. cit., p. 80. 
The assumptions of quality of life ethics are criticised by supporters of the traditional viewpoint. Attention is drawn to the imprecision of the boundary between "rightful" and "wrongful" life (that which is worth living and that which is not) ${ }^{12}$. It is noted that increasing technical possibilities of controlling the biological processes of nature are enabling increasingly dangerous interference with the biological life processes of a human being. There is consequently a fear that technocratic power will lead to the degradation of the individual and commercialisation of the human body ${ }^{13}$. In the view of opponents of quality of life ethics, medicine ought not to determine the value of a person's life, that person being primary and independent. It should simply assume the existence of that value and bring about improvement of the patient's quality of life through medical treatment. What they view as the main problem, however, is that the quality of life principle is a morally dangerous idea, linked to possibilities of eugenic selection, being based on the logic of discrimination and exclusion. It carries with it the temptation to make a distinction between those lives that are deserving of continuation, and those which, in view of their "low quality", ought to be terminated (lives that are not worth living). The opponents of quality of life ethics find such a philosophy to be unsympathetic to the chronically ill, disabled and dying. It becomes a manifestation of the "culture of death" or anti-life logic. It is fundamentally discriminatory since it takes away the right to life in the name of an imprecisely defined quality of life ${ }^{14}$.

Incidentally, doubts of an ethical nature apply also to the taking of decisions by doctors and geneticists as to whether they should provide parents with full information on their child's genetic state, and to the delineation of the rights of parents to take decisions in genetic matters - not only those relating to pregnancy or abortion, but also those which concern the genetic selection of embryos, gamete tests, and the like ${ }^{15}$.

\section{Some remarks on the legal consequences of the creation of a "life not worth living"}

In the context of considerations concerning quality of life ethics, some questions that have already gained classical status relate to claims made on the grounds of wrongful conception. Freedom in the sphere of procreation is associated with the

12 See e.g. T. Biesaga, Wartość życia w ujęciu etyki personalistycznej, Seminare. Poszukiwania naukowe 2003 no. 19, pp. 169-175; http://cejsh.icm.edu.pl/cejsh/element/bwmeta1.element. desklight-7d98499b-ee08-4bee-9fff-d2dc0cdb4a5f? q=bwmeta1.element.cejsh-a89a8c34-949041f6-a9f9-d8755c9f0723;9\&qt=CHILDREN-STATELESS (access 6.4.2018).

13 T. Biesaga, Wartość życia..., op. cit., p. 173.

14 B. Chyrowicz, Zamiar i skutki, Lublin 1997, p. $193 \mathrm{ff}$.

15 R.M. Green, Parental autonomy and the obligation not to harm one's child genetically, Journal of Law, Medicine \& Ethics 1995, vol. 25, p. $2 \mathrm{ff}$. 
granting of the right to abortion in situations where there may be justified grounds for such claims. This is inextricably linked to questions about the consequences of culpable prevention of the exercise of that right. From the standpoint of the topic of this article, the most significant considerations would appear to concern the inability to obtain a legal termination of pregnancy when a child is expected to be born with a lethal defect.

Such situations give rise to court cases concerning wrongful conception: where the parents have made efforts to prevent the birth of a defective child, but due to the doctor's disregard of that fact, birth nonetheless takes place. The result is the birth of a child that is incurably ill (with lethal defects, for example), whose life may be evaluated as "not worth living" 16 . In such cases, charges may be laid against doctors on the ground that they failed to prevent, and indeed declined to eliminate, an impaired life subject to the risk of serious burdens, contrary to the contractual obligation to which they were subject - namely that they did not perform an abortion (or performed it improperly). The doctors thus brought about an unwanted maintenance burden, causing what are known as prenatal injuries. It should be noted that claims on this ground are also made in instances of the birth of healthy children, which in their parents' view for some reason ought not to have been born. Irrespective of the precise reason for a claim of wrongful conception, a key question is whether the creation of a "life not worth living" (or, simply, an unwanted life) may even be considered in terms of harm or injury. This problem has frequently been analysed with reference to court judgments ${ }^{17}$. An affirmative answer to the question has been confirmed in

16 Furthersee: T. Justyński, Poczęcie i urodzenie się dziecka jako źródło odpowiedzialności cywilnej, Kraków 2003; L. Garlicki, Sąd Najwyższy USA a „prawo do życia”, Państwo i Prawo 1992, no. 8; T. Justyński, Urodzenie się dziecka jako źródło szkody. Uwagi na marginesie orzeczenia Sądu Najwyższego RFN z 27.06.1995 r., Prawo i Medycyna 2000, no. 8; T. Justyński, Odpowiedzialność cywilna lekarza w związku z nieudanym zabiegiem sterylizacji ( $w$ świetle prawa niemieckiego), (in:) A. Sokala, E. Gajda (eds.), Honestevivere. Ksiega pamiątkowa ku czci Profesora Władysława Bojarskiego, Toruń 2001; M. Kowalski, Odpowiedzialność odszkodowawcza lekarza z tytułuwrongfulbirthw prawie niemieckim, Prawo i Medycyna 2002, no. 11; W. Lang, W sprawie statusu prawnegonasciturusa, Państwo i Prawo 1983/6; W. Lang, M. Safjan, Odpowiedzialność prawna za szkody prenatalne i prekoncepcyjne, (in:) W. Lang (ed.), Prawne problemy ludzkiej prokreacji, Toruń 2000; M. Nestorowicz, Odpowiedzialność cywilna lekarza wobec narodzonego dziecka $\mathrm{z}$ tytułu wrongful life $\mathrm{w}$ prawie francuskim, (in:) A. Łopatka, B. Kunicka-Michalska, S. Kiewlicz (eds.), Prawo. Społeczeństwo. Jednostka. Księga jubileuszowa dedykowana Profesorowi Leszkowi Kubickiemu, Warsaw 2003; M. Safjan, Rozwój współczesnej medycyny i biologii a prawna ochrona dziecka poczętego, Studia Prawnicze 1988, no. 3; T. Smyczyński, Pojęcie i status prawny dziecka poczętego, Studia Prawnicze 1989, no. 4; T. Smyczyński (ed.), Wspomagana prokreacja ludzka, Poznań 1996.

17 For example, the cases: Christensen v. Thornby; Sciuriaga v. Powell; Emeh v. Kensington and Chelsea and Westminster Area Health Authority; for an analysis of judgments in this area see: T. Justyński, Poczęcieiurodzenie..., op. cit., pp. 35-41. 
numerous judgments (including those of courts in Poland) ${ }^{18}$. The positions adopted by judges would appear to reflect the growing popularity of quality of life ethics ${ }^{19}$.

Another consequence of the popularisation of the principle of quality of life is the ever more frequent pursuit of claims on the grounds of wrongful life and wrongful birth. These apply in particular to life which ought not to have come into existence since it does not meet an appropriate standard of quality and is evaluated as "not worth living" ${ }^{20}$. In considering such cases, judges have to decide what is meant by this term, as well as related terms such as "wrongful life", "wrongful conception" and "wrongful birth". They are required to answer the questions of whether, in allowing somebody's birth, one can be doing harm (injury); whether life as such can constitute injury; and how to estimate the size of such injury. The concept of injury is key to such considerations. There are two types that may arise: prenatal injuries ${ }^{21}$ and preconception injuries ${ }^{22}$.

The term wrongful life may be considered as primary with respect to wrongful birth. This concept has its roots in American case law and is associated with various ideas of quality of life. Although claims on this ground do not concern children with lethal defects, it is appropriate to refer to them, since such claims are evidence of the popularisation of quality of life ethics. Most generally, they relate to complaints by disabled children (the plaintiffs in the cases) who in their own opinion are living in a "grievous state"23. They feel compelled to live a life that is not worth living due to

18 T. Justyński, op. cit., pp. 34-35.

19 Furthersee: A. Breczko, Podmiotowość prawna człowieka warunkach postępu biotechnomedycznego, Białystok 2011, p. 199ff.

20 M. Soniewicka, Regulacje prawne wobec rozwoju nowoczesnych technik kontroli prokreacji. Analiza roszczenia wrongful life, Diametros 2009, no. 19, pp. 137-159.

21 Prenatal injury is associated, in the case of wrongful life claims, with liability in civil law for harm done to a child after conception but before birth. The term is a broad one and covers all kinds of injury done to a nasciturus. It is used in practice in relation to "material damage" done to the foetus by medical personnel. It concerns the causing of health defects as a result of improper actions occurring after the child's conception. The existence of such liability has long been accepted in many legal systems. Typical situations in which it arises include the infection of a pregnant woman with a venereal disease during blood transfusion, transfusion of blood of the wrong group, administration of harmful medication, etc.; see e.g. M. Nestorowicz, Odpowiedzialność cywilna według common law za szkody wyrządzone nasciturusowi przed i po jego poczęciu, Państwoi Prawo1983, no. 8.

22 This class of injury covers circumstances occurring before a child's conception that cause damage to its body or health, if they were the fault of medical personnel. See e.g. M. Nestorowicz, Prawo medyczne, Toruń 2001, p. 175; M. Safjan, Prawo wobec ingerencji w naturę ludzkiej prokreacji, Warsaw 1990, p. 174ff. From the large number of writings on preconception injuries, it may be concluded that there is an increasing trend towards the granting of legal protection to a person even before his or her conception. See T. Justyński, Poczęcieiurodzenie..., op. cit., p. 17.

23 There is a wealth of American literature on preconception injuries; see e.g. J.A. Midlock, Prenatal Injuries Caused by Negligence Prior to Conception: An Expansion of Liability, Chicago-Kent Law 
their mothers' being refused the right to abortion ${ }^{24}$. These plaintiffs argue that it would have been better had they not been born at all. They declare that they would prefer not to live, since their existence does not have a sufficiently "satisfying quality"

The right of every person to be born as a whole, functional being was formulated in a judgment of the New York court of appeal in the case Park v. Chessin ${ }^{26}$. This was the first time that an American court had awarded damages to a child on this ground. Full damages were also awarded in the 1980 case Curlender v. Bio-Science Laboratories $^{27}$. It should be noted that, in spite of the verdicts mentioned here, American courts tend to be unwilling to consider wrongful life claims. Only in exceptional cases do they award damages to disabled children for the "fact of their birth". By the mid-1980s only three US states had granted (partial) legal protection to children born with genetic or developmental defects due to errors made by medical personnel providing preconception and prenatal advice and diagnosis. Until the end of the 1990s such claims were prohibited, either by legislation or by the courts, in the great majority of states. One of the fundamental legal arguments against the recognition of claims for damages for wrongful life referred to the problem of "nonexistence" and the impossibility of deciding whether any kind of existence is better than no existence ${ }^{28}$. In Europe, such damages have so far been awarded only in France and the Netherlands ${ }^{29}$. European courts are therefore highly sceptical as regards the justifiability of such claims. Weronika Chańska claims that the reasons for this may include both the "troublesome" legal issues and - perhaps primarily - the ethical judgments involved in the concept of a "life not worth living"30.

Claims on the ground of wrongful birth are made by the parents of disabled children against doctors who culpably failed to diagnose the defect during pregnancy (or even prior to conception) and thus prevented the pregnancy from being terminated (or caused conception to take place). The doctor is not treated here as the party causing the defects - after all, the "life not worth living" is brought about by nature. The charges against the doctor are solely that, through incorrect diagnosis, he or she deprived the parents (the plaintiffs) of the right to decide whether they wish to accept the "burden" of a defective child. In such cases, redress is not sought for the

Review 1977, vol. 54(2), p. 583; M. Capron, Tort Liability in Genetic Counseling, Columbia Law Review 1979, vol. 79(4), p. 683.

24 W. Chańska, Nieszczęsny dar..., op. cit., p. 69ff.

25 M. Soniewicka, Regulacje prawne..., op. cit., p. 137.

26 387, N.Y.S. Zd. 204 (1976).

27106 Cal App 3 d 811, 165 CalRptr 477 (1980).

28 A thorough analysis of judgments in this area was made by J. Różyńska, „Wolałbym nie istnieć, niż żyć w takim stanie". O koncepcji krzywdy opartej na racjonalnej preferencji Joela Feinberga, Etyka 2014, no. 49, pp. 59-82.

29 W. Chańska, Nieszczęsny dar..., op.cit., p. 70.

$30 \quad$ Ibidem, p. 71. 
The Question of the Value of Human Life in Theoretical Discussions and in Practice...

serious defects suffered by the child; the plaintiff seeks damages for the very fact of the "wrongful birth".

It is indeed difficult to decide whether the right to autonomy in matters of procreation ought to include the right to decide in the matter of a possible abortion, or whether the right of every being to life implies the impossibility of deciding - without that being's expressed will - to take away that life. Nonetheless, claims for wrongful conception, wrongful life and wrongful birth have become a "signal" of modern times. They provide an example of the ever clearer contradiction in moral and legal evaluations ${ }^{31}$. The traditional concepts and legal constructs are confronted with an entirely new social reality. Analysis of theory and practice leads to the conclusion that such cases cannot be downplayed. The arguments advanced on the basis of quality of life ethics might indicate that a person's right to dignity and autonomy ought to imply the need to create appropriate legal regulations to enable such claims.

\section{Can someone be injured by being brought to life?}

A fundamental question inherently connected with claims for wrongful life is whether nonexistence can be better than existence. Can a person be injured by being brought to life, in a situation where at the prenatal stage it was known that the person would be born with a congenital untreatable disease or disability? This problem has been the subject of debate in the ethical and legal literature ${ }^{32}$. The controversies relate to whether it is even justified for courts to award compensation for the "harm of existence". Such harm relates to the fact of the creation of a life branded with pain and suffering, and moreover associated with particular needs and costs. Without examining in detail the various ways of understanding the very concept of "harm of existence", let us consider an interesting proposal of Joel Feinberg. That author, aware of the impossibility of comparing existence with nonexistence, views such harm through the lens of a "rationalisation of preference". He states that, if potential parents have good reason to suppose that their child's life will be one of poor quality, they ought not to allow such a life to come into being. In his view, by consciously calling the child into existence, they are doing it harm. Their decision is therefore prima facie morally wrong. When precisely may we speak of the "harm of existence"? Feinberg proposes attempting to imagine a situation in which a person might rationally prefer immediate death to continued life. Let us thus imagine that, after death, a person is received by a deity who makes the following proposition: either you are to be born

\footnotetext{
31 P. Jaworek, Narodziny dziecka jako źródło szkody w prawie cywilnym, (in:) M. Warciński, K. Zaradkiewicz (eds.), Wybrane zagadnienia prawa cywilnego, Warsaw 2006, p. 57ff. 
again as a child with a fatal disease (such as Tay-Sachs disease) ${ }^{33}$, or you are to be instantly annihilated. By choosing the first option, they will gain up to four years of life full of pain and suffering, ending once again in death. Feinberg claims that one would have to be mad to choose the first option, just as a rational person would not hesitate to choose immediate nonexistence if the deity required them to choose between the same alternatives on behalf of a person they loved and truly cared for, such as a spouse or child ${ }^{34}$. In his view, every rational thinking person would choose the option of "not-existing" in such a situation. The thought experiment thus demonstrates that it is possible to have a rational preference for nonexistence ${ }^{35}$. Naturally, this applies only to exceptional, extreme cases ${ }^{36}$. One may assert that parental autonomy in deciding whether a child with serious genetic defects should come into the world does not always justify in an obvious way a decision as to the child's birth. What is morally controversial may be the fact that, having a choice between a healthy child and one with severe genetic defects, a parent might consciously choose the latter ${ }^{37}$.

\section{On the legitimacy of the right to abortion in the case of a foetus with lethal defects}

Under current Polish law, abortion is permitted in case of severe and irreversible impairment of the foetus (in accordance with the so-called "criteria model"). In the bioethical debate concerning this issue - which in Poland proves still to be controversial - arguments of substance are relegated to a secondary role. In the ongoing discussions concerning the Stop Abortion proposal, there is some visible manipulation. The "anti-choice" campaigners use images of smiling children with Down's syndrome as an argument for a ban on what they call "eugenic abortion". The aforementioned proposal would remove from Polish law the "embryopathological criterion" (one of only three exceptions allowing legal termination in what is already the most restrictive anti-abortion legislation in Europe $)^{38}$. The references made

33 This is an onerous and incurable disease, detectable in prenatal diagnosis. Its effects include neurological damage, intellectual disability, deafness, blindness and other serious developmental defects, leading to death at an age of around 2-3 years. http://neuropsychologia.org/choroba-taysachsa (6 April 2018).

34 J. Feinberg, Wrongful Life and the Counterfactual Element in Harming, Social Philosophy and Policy 1986, vol. 4, p. 22.

35 J. Feinberg, Harm to Others, The Moral Limits of Criminal Law 1987, vol. 4.

36 B. Steinbock, Life Before Birth: The Moral and Legal Status of Embryos and Fetuses, Second Edition, Oxford 2011, p. 124.

37 D. Szawarska, Preimplantacyjna diagnoza genetyczna (PGD) i zasada odpowiedzialności rodzicielskiej, (in:) A. Krawczak, E. Maciejewska-Mroczek, M. Radkowska-Walkowicz, Dziecko. In vitro. Społeczeństwo. Ujęcie interdyscyplinarne, Warsaw 2018, p. 229.

38 Polish Act of 7 January 1993 on family planning, protection of human foetuses and conditions for the admissibility of termination of pregnancy (Dz.U. 1993 No. 17 item 78). 
The Question of the Value of Human Life in Theoretical Discussions and in Practice...

- in the debate over planned changes to abortion law - to "eugenic abortion" are, we believe, an oversimplification. The category of "eugenic considerations" is indeed used in the philosophy of law and in bioethics, these being listed among the conditions that justify abortion. However, these are cases where there has been found to be a risk to the life or health of the mother, or else serious developmental defects or damage to the foetus ${ }^{39}$. They should not be identified with a treatment of abortion as a means of controlling births, as would be implied by the pejorative connotations of "eugenics". Eugenics, in the version proposed by Francis Galton, was to be a method of improving the genetic material of a race, nation, species or whole society, controlled by a central authority. To ascribe similar intentions to parents taking a decision to terminate a pregnancy because of a fatal defect of the foetus would appear unjustified and even unethical. Great caution should be exercised in attempting to juxtapose, or even identify, the concept of abortion with that of eugenics. Such a view would appear not to take account of the fact that decisions in such a complex matter are accompanied by moral dilemmas experienced by the person deciding about a possible abortion. It is also difficult to regard the concept of procreative freedom as equal to the treatment of abortion as a procedure available "on demand". In such a significant discussion, arguments on either side should not be devoid of sensitivity to ethical values, and all the more so should not be formulated under the influence of popular opinions, ideology or manipulation.

The definition of a developmental defect in medicine is a very broad one. Not every such defect is considered in law as a ground for abortion. Certainly, "lethal defects" are currently regarded as such a ground (and should continue to be). These are the most serious developmental anomalies, for which the medical prognosis is poor - in terms of not only the possibility of treatment, but in particular the possibility of mere survival. They usually result in miscarriage or the birth of a dead child. Only in rare cases is there a chance of a live birth, but even then, the child usually dies while still a baby: 95\% die before the age of one year. Even if the child survives, it is not possible to establish any contact with him or her. This occurs, for example, in the case of newborns with Edwards syndrome or with anencephaly (lacking a cerebral cortex). The existence of such beings is associated with incredible burdens, being accompanied by intellectual disability, serious heart defects, convulsive fits, bone and skeletal defects, obstruction of the oesophagus, respiratory disturbances, defects in the formation of the face, eye defects (from anophthalmia to cyclopia), microcephaly, polydactyly, cleft palate, and many other conditions. Only in isolated cases do children with "lethal defects" survive to adulthood, and even then, they are subject to numerous limitations and the need for constant care ${ }^{40}$.

39 T. Pietrzykowski, Spór o aborcję, Katowice 2007, pp. 26-27.

40 https://oko.press/bezoczne-mozg-poza-czaszka-zarosniecie-przelyku-brzydkie-dzieci-wadamiwrodzonymi (access 6.4.2018). 
The question therefore arises: do we have the right to condemn these seriously handicapped human beings to several months (sometimes several years) of existence under such enormous burdens, in the name of the principle of sanctity of life? Can a life that is limited solely to the experiencing of an untreatable disease, suffering (accompanied by the absence of any awareness) and waiting for death be regarded as a value in itself? It should be considered that the creation of such a life will undoubtedly lead to suffering not only on the part of the parents (particularly the woman required to carry her pregnancy to term knowing that the child will die soon after birth), but also on the part of the child, who - before death arrives - will be forced to undergo a number of onerous medical procedures such as mechanical ventilation, continuous painkilling treatment, and possibly - in the case of more favourable prognoses - dozens of surgical operations. It is unquestioned that every human being has the constitutional right to life and a legal guarantee of the protection of his or her dignity; but in such cases the question arises whether the value of life is in every instance an exceptionless premise for the maintenance of biological existence ${ }^{41}$.

It seems that one must agree with Joanna Różyńska's observation that the right to abortion in such cases protects the right of parents to take an informed decision on whether they wish to and are able to take on the responsibility of caring for a child that requires such special attention. It also protects the welfare of the incurably sick child. As she rightly states, to perceive the suffering of others and assume moral responsibility for the quality of the life that we give to a child, we do not have to undertake the formidable task of comparing "existence" with "nonexistence" 42 .

The question of the legal regulation of abortion should not be treated as an attack directed against the principle of the protection of human life. It should rather be understood as a legal guarantee of freedom of choice in a morally controversial situation. The granting of such a choice "does not compel anyone to regard abortion as a justified exception from the protection of human life if they do not share that view, whereas a legal ban on abortion forces those of the opposite view to act as if they regarded abortion as a morally unacceptable attack on the 'sanctity' of life" ${ }^{33}$. It seems that the law cannot force people into heroism, even if this takes place in the name of the dogmas of the country's dominant religion. The authorities should nonetheless support children born into a "state of harm" and their "heroic parents". Is it a good solution that such support be provided in the form of compensation

41 We should add that, although the treatment of life as an absolutely overriding and autotelic value is a fundamental assumption, exceptions from it may be admitted in certain extreme situations. Cases are known where the value of life and the need to protect it come into conflict with other values, such as honour or obligations to one's country. Exceptions on grounds of self-defence and "higher necessity" might also be mentioned.

T. Pietrzykowski, Etyczne problemy prawa, Warsaw 2011, p. 136. 
The Question of the Value of Human Life in Theoretical Discussions and in Practice...

awarded for a "life not worth living"? Certainly this should not be the sole solution; particularly since it often leads to the stigmatisation of the people making such claims - as wishing to profit from their misfortune - which may undoubtedly strike at their sense of dignity.

\section{Conclusions}

Traditionally oriented ethics has addressed the description and classification of protection of human life using the concept of value, understood as autotelic value. The determinant of the protection of this value is the idea of the sanctity of life. This view has been influenced by religious concepts related to the sanctity of life, viewed as an objective value, constituting a "gift". On this basis, human life is assigned per se a special value that distinguishes people from other species. Modern bioethical thinking takes account also of another perspective, that of quality of life. This attitude results from a redefinition of the assumption that the granting of a particular value to the lives of representatives of the human species arises from mere biological membership of that species ${ }^{44}$. It is pointed out that the valuing of human life may depend on a human's possession of certain properties, such as consciousness, the ability to feel, and so on. The treatment of the value of life as an attribute having an absolute nature, though morally and axiologically justified, is not the only perspective for understanding the protection of life and the relation of that value to other important and legally protected values.

The challenges brought about by technological and medical progress force legislators to make significant axiological choices. It is not easy to decide whether legal regulations may be a sufficiently effective and refined tool for the positivisation of the problem of quality of life. Certainly, though, the regulation of such subtle questions should not be a source of irreducible divisions and conflicts but should rather be a tool of consensus. In a situation where traditional legal categories come up against changes in science and in social reality, it is important and desirable for a set of moral values to be developed which might serve as a universal point of reference in deciding these cases, which are difficult both morally and legally.

\section{BIBLIOGRAPHY}

Bazela M.,Życie wysokiej jakości, czyli po co nam bioetyka?, Archeus. Studia z bioetyki i antropologii filozoficznej 2004, vol. 5.

Biesaga T., Wartość życia w ujęciu etyki personalistycznej, Seminare. Poszukiwania naukowe 2003, no. 19.

44 Such an extreme anthropocentric perspective is seen by some bioethicists as a manifestation of speciesism; see P. Singer, Etyka praktyczna, Warsaw 2003, p. 65, passim. 
Breczko A., Podmiotowość prawna człowieka warunkach postępu biotechnomedycznego, Białystok 2011.

Capron M., Tort Liability in Genetic Counseling, Columbia Law Review 1979, vol. 79(4).

Chańska W., Nieszczęsny dar życia. Filozofia i etyka jakości życia w medycynie współczesnej, Wrocław 2009.

Chyrowicz B., Zamiar i skutki, Lublin 1997.

Feinberg J., Harm to Others, The Moral Limits of Criminal Law 1987, vol. 4.

Feinberg J., Wrongful Life and the Counterfactual Element in Harming, Social Philosophy and Policy 1986, vol. 4.

Fletcher J., Indicators of Humanhood: A Tentative Profile of Man, The Hastings Center Report 1972, vol. 2.

Garlicki L., Sąd Najwyższy USA a „prawo do życia”, Państwo i Prawo 1992, no. 8.

Green R.M., Parental autonomy and the obligation not to harm one's child genetically, Journal of Law, Medicine \& Ethics 1995, vol. 25.

Jaworek P., Narodziny dziecka jako źródło szkody w prawie cywilnym, (in:) M. Warciński, K. Zaradkiewicz (eds.), Wybrane zagadnienia prawa cywilnego, Warsaw 2006.

John Paul II, Encyclical: Evangelium Vitae. On the value and inviolability of human life, Vatican 1995, no. 2 .

Justyński T., Odpowiedzialność cywilna lekarza w związku z nieudanym zabiegiem sterylizacji (w świetle prawa niemieckiego), (in:) A. Sokala, E. Gajda (eds.), Honestevivere. Księga pamiątkowa ku czci Profesora Władysława Bojarskiego, Toruń 2001.

Justyński T., Poczęcie i urodzenie się dziecka jako źródło odpowiedzialności cywilnej, Kraków 2003.

Kowalski M., Odpowiedzialność odszkodowawcza lekarza z tytułu wrongfulbirth w prawie niemieckim, Prawo i Medycyna 2002, no. 11.

Krawczak A., Maciejewska-Mroczek E., Radkowska-Walkowicz M., Dziecko. In vitro. Społeczeństwo. Ujęcie interdyscyplinarne, Warsaw 2018.

Lang W., W sprawie statusu prawnego nasciturusa, Państwo i Prawo1983, no. 6.

Lang W., Safjan M., Odpowiedzialność prawna za szkody prenatalne i prekoncepcyjne, (in:) W. Lang (ed.), Prawne problemy ludzkiej prokreacji, Toruń 2000.

McCormick R.A., The Quality of Life, the Sanctity of Life, The Hastings Center Report 1978, vol. 8.

Midlock J.A., Prenatal Injuries Caused by Negligence Prior to Conception: An Expansion of Liability, Chicago-Kent Law Review 1977, vol. 54(2).

Nestorowicz M., Odpowiedzialność cywilna lekarza wobec narodzonego dziecka z tytułuwrongful life w prawie francuskim, (in:) A. Łopatka, B. Kunicka-Michalska, S. Kiewlicz (eds.), Prawo. Społeczeństwo. Jednostka. Księga jubileuszowa dedykowana Profesorowi Leszkowi Kubickiemu, Warsaw 2003.

Nestorowicz M., Odpowiedzialność cywilna według common law za szkody wyrządzone nasciturusowiprzed i po jego poczęciu, Państwo i Prawo1983, no. 8.

Nestorowicz M., Prawo medyczne, Toruń 2001. 
Nordenfelt L., Quality of Life. Health and Happiness, Avebury, Aldershot 1993.

Nussbaum M., Sed A. (eds.), The Quality of Life, Clarendon Press, Oxford 1993.

Pietrzykowski T., Spór o aborcję, Katowice 2007.

Pietrzykowski T., Etyczne problemy prawa, Warsaw 2011.

Różyńska J., „Wolałbym nie istnieć, niż żyć w takim stanie”. O koncepcji krzywdy opartej na racjonalnej preferencji Joela Feinberga, Etyka 2014, no. 49.

Safjan M., Prawo wobec ingerencji w naturę ludzkiej prokreacji, Warsaw 1990.

Safjan M., Rozwój współczesnej medycyny i biologii a prawna ochrona dziecka poczętego, Studia Prawnicze1988, no. 3.

Shelp E.E., Born to die? Deciding the fate of critically ill newborns, New York 1986.

Singer P., Etyka praktyczna, Warsaw 2003.

Singer P., O życiu i śmierci. Upadek etyki tradycyjnej, Warsaw 1994.

Smyczyński T. (ed.), Wspomagana prokreacja ludzka, Poznań 1996.

Smyczyński T., Pojęcie i status prawny dziecka poczętego, Studia Prawnicze1989, no. 4.

Soniewicka M., Regulacje prawne wobec rozwoju nowoczesnych technik kontroli prokreacji. Analizaroszczenia wrongful life, Diametros 2009, no. 19.

Steinbock B., Life Before Birth. The Moral and Legal Status of Embryos and Fetuses, Second Edition, Oxford 2011.

Szawarska D., Preimplantacyjna diagnoza genetyczna (PGD) i zasada odpowiedzialności rodzicielskiej, (in:) A. Krawczak, E. Maciejewska-Mroczek, M. Radkowska-Walkowicz, Dziecko. In vitro. Społeczeństwo. Ujęcie interdyscyplinarne, Warsaw 2018.

Szawarski D., Wartość życia, Etyka 1984, no 21, pp. 41-69.

Ślęczek-Czakon D., Problem wartości i jakości życia w sporach bioetycznych, Katowice 2004.

Tokarczyk R., Jakość życia jako prewartość, http://romantokarczyk.pl/juris/bio8.html (6 April 2018).

Umiastowski J., Wokół kodeksu etyki lekarskiej, Ethos 1994, nos. 1-2. 